\title{
Paraffin-Graphite Based Composite Electrodes as Substrate for the Electrodeposition of Conductive Films with Analytical Purposes
}

\author{
Fonseca, C. A.;* dos Santos, T. A. D.; Resende, A. C.; Semaan, F. S. \\ Rev. Virtual Quim., 2013, 5 (4), 538-547. Data de publicação na Web: 12 de agosto de 2013 \\ http://www.uff.br/rvq
}

\section{Eletrodos Compósitos a Base de Grafite e Parafina como Substrato para Eletrodeposição de Filmes Condutores para Fins Eletroanalíticos}

Resumo: Visando a utilização de eletrodos compósitos como plataforma de modificação para fins analíticos, compósitos a base de carbono e parafina foram produzidos. Para utilização desses eletrodos, primeiro a área eletroativa foi calculada e em seguida as modificações efetuadas. Para tal, o azul da Prússia, o vermelho neutro e o cobre metálico foram usados como modificadores superficiais. As duas primeiras deposições foram efetuadas por meio da técnica de voltametria cíclica e para o cobre metálico foi utilizada uma galvanoplastia de potencial constante. Como analitos, tanto com o azul da Prússia, quanto com o vermelho neutro, foi estudado o peróxido de hidrogênio através da detecção amperométrica e, com o cobre foi usado etanol pelo emprego da voltametria cíclica.

Palavras-chave: Compósitos; Modificação; Eletrodos.

\begin{abstract}
In order to use composite electrodes as modification platform for analytical purposes, carbon was used as solid and paraffin as liquid phase in the composite preparation. To the electrodes use, first the electroactive area was determined and then the modifications were done. To this purpose, Prussian blue, neutral red and metallic copper were used. The two first depositions were done by cyclic voltammetry technique and the third one, by electroplating with constant potential. As analite, hydrogen peroxide was studied in the two first cases with amperometric detection and, in the third case, ethanol with cyclic voltammetry.
\end{abstract}

Keywords: Composite; Modification; Eletrodo.

\footnotetext{
* Universidade Federal Fluminense, Departamento de Química Analítica, Rua Outeiro de São João Batista s $/ \mathrm{n}^{0}$, CEP 24020-141 Niterói-RJ, Brasil.

M cristiano-uff@hotmail.com

DOI: $10.5935 / 1984-6835.20130041$
} 


\title{
Paraffin-Graphite Based Composite Electrodes as Substrate for the Electrodeposition of Conductive Films with Analytical Purposes
}

\author{
Cristiano A. Fonseca, ${ }^{*}$ Thiago A. Drumond dos Santos, Adriano C. \\ Resende, Felipe S. Semaan \\ Universidade Federal Fluminense, Departamento de Química Analítica, Rua Outeiro de São \\ João Batista s $/ n^{0}$, CEP 24020-141 Niterói-RJ, Brasil. \\ *cristiano-uff@hotmail.com
}

Recebido em 22 de novembro de 2013. Aceito para publicação em 2 de agosto de 2013

\section{Introduction}

\section{Experimental}

2.1. Preparation and assessment of composite electrode composition

2.2. Electrochemical methods

\section{Results and Discussion}

3.1. Determination of electroactive area using an outer-sphere probe

3.2. Deposition of Prussian blue film

3.3. Deposition of poly-neutral red film

3.4. Deposition of a copper thin film

\section{Conclusions}

\section{Introduction}

According to Tallman and Petersen, a composite is a mixture of different components being it homogeneous when seen in macroscopic scale and heterogeneous in microscopic scale. In electrochemistry, electrodes composites are associated to a blend of at least a conductor phase and an insulating one, being characterized by the proportion between them. ${ }^{1-3}$ Different proportions will lead to more rigid or malleable electrodes. The fabrication versatility of these materials allows the construction of different forms and sizes, and also the introduction of chemistry modifiers improving the selectivity and sensibility, and further, the possibility of surface renewal keeping the properties. ${ }^{4,5}$ Many are the advantages about using composites in the elaboration of electrodes. Besides the fabrication versatility, the sizes and forms, inputting of modifiers, it can be used in a large range of $\mathrm{pH}$ and solvents, it shows good electric conduction, stability, large potential range and low cost if compared to others electrodes such as metallic or diamond ones, for example. . $^{3,5-7}$ 
Graphite composites have high intrinsic resistance and very low relaxation time, if compared with the time scale of the electrochemistry processes, in this way, parameters and details about the percolation phenomena trough the solid can be neglected, giving to these composites the title of perfect resistors. ${ }^{8,9}$

The same conclusions may be taken from the comparison between the double layer capacitance and the results of electrochemistry impedance spectroscopy (EIS); such values can be $<1 \mu \mathrm{F} / \mathrm{cm}^{2}$ for highly oriented pyrolytic graphite (HOPG) or $>>70$ $\mu \mathrm{F} / \mathrm{cm}^{2}$ for materials less organized. Carbon materials have a non-classic component that increases the capacitance more than the expected value for the double layer effects. ${ }^{10}$

Once any form of carbon available as a conductor phase is chosen, the evaluation and development of new insulating phases is the next step to improve the performance, sensibility and selectivity of the sensors. Such studies have been growing significantly, mainly with the news materials available, with several properties. ${ }^{11,12}$ Between the insulating phases can be cited paraffin, silicon, bromonaphthalene and esters, and also organic phosphates and phthalates. 5

Paraffin, however, has a great potential for being used, due to the fact that it is easily found, easy to deal with, easy to regenerate the surface when necessary, and also due to its low cost. Looking for more specific and selective applications, modification is usually applied to composites electrodes because of its facility. In this way, there are two possibilities: bulk and surface modification.

The hexacianoferrates' chemistry as electrochemical materials, and also its applications, have been widely studied. ${ }^{13,14}$ Insoluble films made by these compounds have large applicability as electrochromic materials and redox mediator, turning them into attractive surface modifiers. These characteristics together with its facility of obtaining and low costs, stimulates its use, especially as support for biosensors, ${ }^{15,16}$ as simultaneous analysis sensors or electrocatalysis. ${ }^{17,18}$

Generally, hexacianometalates are studied not only by their electrochromic properties, but also by their potential as mediators of electron transfer in many sensors and biosensors, being them simple or not. $^{19}$ These substances are polinuclear inorganic compounds involving transition metals as iron, ruthenium, copper, molybdenum, vanadium and nickel. ${ }^{13}$

Different strategies have been described for the Prussian blue (PB) deposition as a film on different substrates. Among them, galvanostatic by current application, or the chronoamperometric are examples. ${ }^{14}$ Intending to facilitate such procedures, cyclic voltammetry has been widely described and recommended for the equivalent films achievement but in a faster way. ${ }^{13,14,18}$ Not only are inorganic compounds used in surface modifications, but also metallic depositions.

In the development of modified electrodes the use of electropolymerisation is a very useful tool, since these materials have different properties if compared to its monomers. ${ }^{20}$

Electroactive polymers in electrolyte solutions can exhibit favourable behavior in relation to electronic and ionic conductivity, which makes it favourable to electrocatalysis be it in oxidative or reductive process; $;^{21,22}$ and despite the fact that their behaviour is not selective, the film's formation with controlled dimensions, together with the adequate use of enzymes, can offer to the developed sensors selectivity and sensibility enough to their use in bioanalysis. Between the organic conductive polymers, the phenazines are the most used due to its application in sensors and biosensors. ${ }^{23}$ Many are the compounds inside this category, such as neutral red, methylene green, methylene blue, safranin, phenosfranin, toluidine blue, and more. As the Prussian blue, organic conductive polymers can be obtained from many ways, being the most common way voltammetry under controlled conditions such as $\mathrm{pH}$, ionic strength, potentials and sweep speed. ${ }^{21,22,24}$ 
Anodic oxidation of alcohol and aldehydes are well known as being easily done with copper electrodes. However, there is no such a vast literature about the use of copper as a sensor in alcohol detection. ${ }^{25}$

This kind of detection is very important for commercial necessities and for the realms of health. Usually it is done by techniques such as chromatography, mass spectrometry, fluorimetry, calorimetry, and others. However, these techniques are more sophisticated and have a high cost associated not only due to the equipment, but also the use of solvents and sometimes sample treatment, which make the analysis longer as well. ${ }^{25,26}$

\section{Experimental}

2.1. Preparation and assessment of composite electrode composition

Composite electrodes were prepared by mechanical dispersion of graphite particles (Sigma Aldrich Chemistry, diameter $<20 \mu \mathrm{m}$, EUA) in paraffin (Solven Wax 170/190, Brazil). Different proportions from $65-80 \%$ were prepared by weighing suitable masses of paraffin and graphite, being the mixtures heated and homogenised at $55-60{ }^{\circ} \mathrm{C}$ (melting point of the insulating phase in use), blends were then pressed inside the support (an adapted syringe).

\subsection{Electrochemical methods}

The electrochemical methods have used the composites electrodes prepared as work electrodes in a three electrodes electrochemistry cell, with $\mathrm{Ag} \mid \mathrm{AgCl}$ as reference and platinum as counter electrode. The solutions used were all prepared with bidistillated water.

The equipment used was a potentiostat with integrated module for electrochemistry impedance spectroscopy, Ivium, CompactStat (Ivium Tecnologies, Holand), controlled by portable microcomputer with an IviumSoft software.

\subsubsection{Determination of electroactive area using an outer-sphere probe}

The electroactive areas were calculated from cyclic voltammetry data, using potential range of $-0.2 \mathrm{~V}$ to $+0.8 \mathrm{~V}$, step of $10 \mathrm{mV}$ and varying the velocity between 10 and $100 \mathrm{mV}$ $\mathrm{s}^{-1}$. A $0.5 \mathrm{~mol} \mathrm{~L}^{-1} \mathrm{KCl}$ solution were used as support electrolyte and a $5 \times 10^{-3} \mathrm{~mol} \mathrm{~L}^{-1}$ $\mathrm{K}_{3}\left[\mathrm{Fe}(\mathrm{CN})_{6}\right]$ solution as active electrolyte.

\subsubsection{Deposition of Prussian blue film}

The electrodeposition of Prussian Blue were made by cyclic voltammetry within 10 to 20 complete cycles with a potential range of $-0.2 \mathrm{~V}$ to $+1.0 \mathrm{~V}$ and velocity of $50 \mathrm{mV} \mathrm{s}^{-1}$ in a $50.0 \mathrm{~mL}$ solution prepared by $\mathrm{KCl} 0.1 \mathrm{~mol} \mathrm{~L}^{-}$ ${ }^{1}, \mathrm{HCl} 0.01 \mathrm{~mol} \mathrm{~L}^{-1}, \mathrm{~K}_{3}\left[\mathrm{Fe}(\mathrm{CN})_{6}\right] 0.6 \mathrm{mmol} \mathrm{L}^{-1}$, and $\mathrm{FeCl}_{3} .6 \mathrm{H}_{2} \mathrm{O} 0.6 \mathrm{mmol} \mathrm{L}^{-1}$.

\subsubsection{Deposition of poly-neutral red film}

In order to obtain the neutral red film, cyclic voltammetry was used with a potential range of -1.0 and $+1.2 \mathrm{~V}$ (vs $\mathrm{Ag} \mid \mathrm{AgCl})$; speed of $50 \mathrm{mV} \mathrm{s}^{-1}$ in a controlled stirring environment and the neutral red's solutions with a concentration of $1.4 \mathrm{mmol} \mathrm{L}^{-1}$ in a phosphate buffer solution ( $\mathrm{pH}$ 5.5).

\subsubsection{Deposition of a copper thin film and ethanol detection}

Copper sulphate solutions were prepared by $15.66 \mathrm{~g}$ of the pentahydrate salt in $100 \mathrm{~mL}$ of a $1 \mathrm{~mol} \mathrm{~L}^{-1} \mathrm{H}_{2} \mathrm{SO}_{4}$ solution. The deposition 
was made by electroplating with a fixed potential of $-0.5 \mathrm{~V}$ in a convection system of $150 \mathrm{rpm}$, using the copper sulphate acid saturated solution. 1500 dots were spotted with an interval of $0.2 \mathrm{~s}$ between the dots $(5$ minutes). After the deposition, the electrode was ready to be used.

Ethanol analysis were made by cyclic voltammetry, in $50 \mathrm{~mL}$ of a $0.8 \mathrm{~mol} \mathrm{~L}^{-1} \mathrm{NaOH}$ solution, and absolute ethanol diluted 1:2 $(48 \%)$ were used. The potential range was of $-0.7 \mathrm{~V}$ to $+1.0 \mathrm{~V}$, with a velocity of $10 \mathrm{mV} \mathrm{s}^{-1}$. Only one cycle was used, and $0.5 \mathrm{~mL}$ was used for all additions. The technique was applied for the electrode with the copper deposited and for the electrode without it. The same conditions were kept in all the tests.

\section{Results and Discussion}

\subsection{Determination of electroactive area using an outer-sphere probe}

The geometric area does not always agree with the electroactive area, mainly when the material used is finely divided. In electrochemistry, all the phenomena occur at the surface, so the electroactive area is very important. The electroactive area's calculation of the composites made were done by the cyclic voltammetric techniques in a $\mathrm{KCl} 0.5 \mathrm{~mol} \mathrm{~L}^{-1} \mathrm{e} \mathrm{K}_{3}\left[\mathrm{Fe}(\mathrm{CN})_{6}\right] 5 \times 10^{-3} \mathrm{~mol}$ $\mathrm{L}^{-1}$ solution, with velocities from 10 to $100 \mathrm{mV}$ $\mathrm{s}^{-1}$, in a potential window of $-0.2 \mathrm{~V}$ to $+0.8 \mathrm{~V}$. After the measures, with the values of the cathodic peaks, the electroactive area's calculation was done with the equation:

$$
i_{p c}=\left(2,69 \times 10^{5}\right) n^{2 / 3} A D_{0}^{1 / 2} v^{1 / 2} C_{0}
$$

Considering the reactions as reversible, in other words, considering that the velocities are sufficiently fast so that there is a dynamic equilibrium at the surface, the current of the peak, in Ampere, is given by the equation (1). Where, " $n$ " is the number of electrons involved in the process, " $A$ " is the electroactive area of the electrode, " $D_{0}$ " is the diffusional coefficient in $\mathrm{cm}^{2} \mathrm{~s}^{-1}$, " $\mathrm{C}_{0}$ " is the species concentration in solution in mol $\mathrm{cm}^{-3}$ and " $\mathrm{v}$ " is the velocity in $\mathrm{V} \mathrm{s}^{-1}$. Assuming " $\mathrm{n}$ " as $1, \mathrm{D}_{0}$ and $\mathrm{C}_{0}$ as known values, the " $\mathrm{v}$ " as a stipulated value and the $i_{p c}$ as the signal obtained from the analysis, the " $A$ " is the only unknown value in the equation (1). In this way, the electroactive area can be easily calculated by the average of the velocities. In low proportions, the surface reproducibility cannot be guaranteed, since the system, microscopically, is less compact, allowing greater randomness of the graphite particles in paraffin. At the same time, the addition of carbon in the system do not implies a proportional addition of conductivity. This happens because the electroactive area has the contribution not only of the conductivity of the carbon, but also the insulating of the paraffin, resulting in a nonlinear dependence of the electroactive area with the graphite.

\subsection{Deposition of Prussian blue film}

The voltammetric profile of the electrodeposition is represented below (Figure 1). In order to apply the modified electrode in the detection of the $\mathrm{H}_{2} \mathrm{O}_{2}$, and to study the improvement of the electrode's response after the modification, some experiments were made using the amperometry in gentle stir, with a potential of $-0.35 \mathrm{~V}$ in a $50 \mathrm{~mL}$ phosphate buffer, $\mathrm{pH}$ 7.0 , with successive additions of $0.50 \mathrm{~mL}$ of a standard $\mathrm{H}_{2} \mathrm{O}_{2}$ solution in $25.5 \mathrm{mmol} \mathrm{L}^{-1}$. In the Figure 2 the amperometric profiles using the composite with the Prussian Blue film and without the film are shown.

The result shows clearly the improvement of the electrode's response. In this case, the previously optimization has shown 10 cycles as the best condition for the electrodeposition, a more elevated value results in a thicker and more unstable film. 


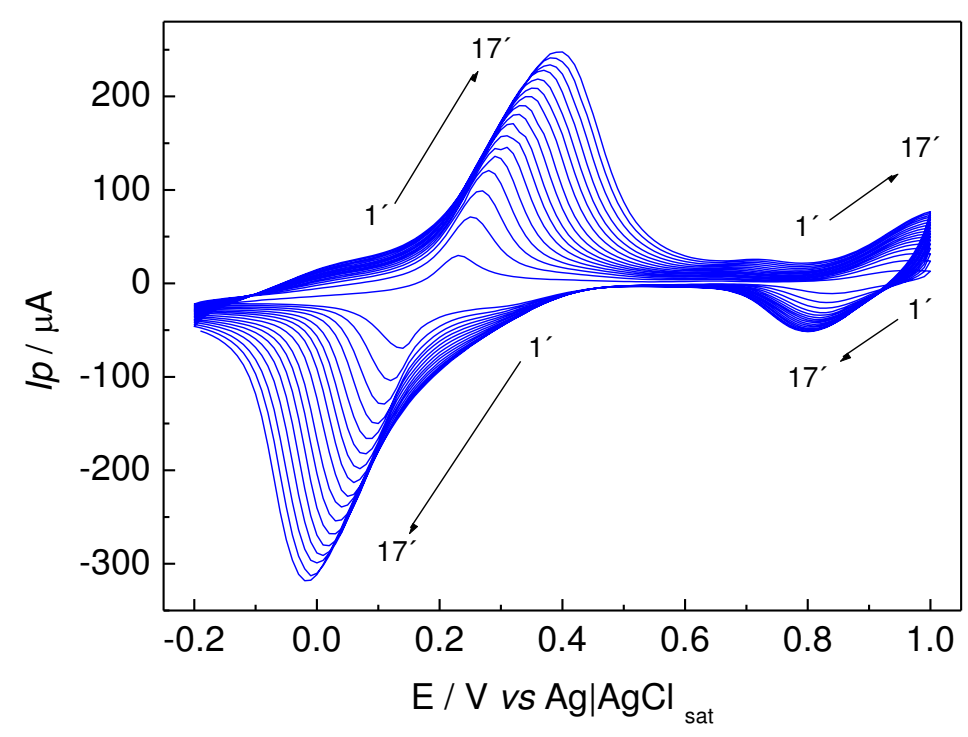

Figure 1. Voltammetric profiles (from $1^{\text {st }}$ to $17^{\text {th }}$ cycle) of the electrodeposition process of the Prussian blue on the composite

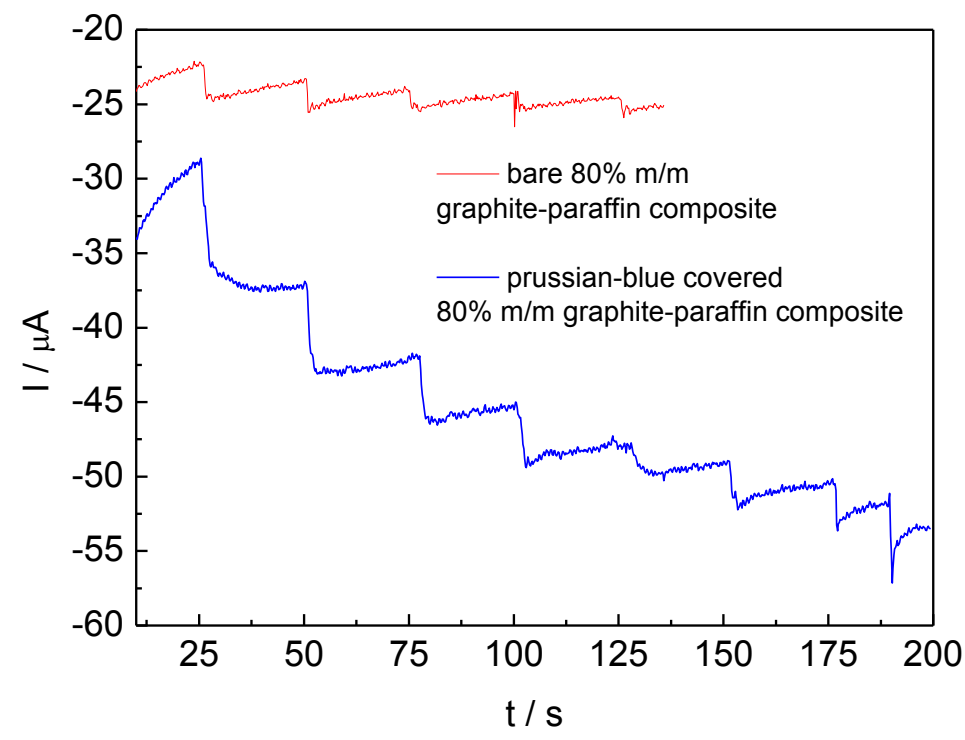

Figure 2. Comparison between the profiles for successive additions of $0.50 \mathrm{~mL}$ of a standard $\mathrm{H}_{2} \mathrm{O}_{2}$ solution ( $25.5 \mathrm{mmol} \mathrm{L}^{-1}$ ) using the composite before and after the modification

\subsection{Deposition of poly- neutral red film}

The following profile (Figure 3) was obtained after twenty successive cycles with the electrode immersed in the previous solution. The obtained film was identified as a thin red translucent pellicle. Optimizing the conditions of poly-neutral red's electrodeposition, an experiment was carried out in order to evaluate its power as mediator in bioanalysis. The amperometry 
was used to detect the hydrogen peroxide. Figure 4 shows the amperometric profile, in which two additions of $500 \mu \mathrm{L}$ of hydrogen peroxide $30 \%$ were made with a potential of $-350 \mathrm{mV}$. The result shows the sensibility's improvement in the electrode with the neutral red film. Attempts to reproduce this result failed, which makes the use of this system useless in the real sample detection. The molecular oxygen is a possible interference at negatives potentials, so nitrogen was burbled in the solutions before the analysis in order to verify it. However, there was no success, since the electrode was inactive toward the peroxide addictions. Variables were evaluated such as potential applied, ionic strength of the electrodeposition's medium, light exposure of the film and packaging, although none of them had good results such as Figure 4 .

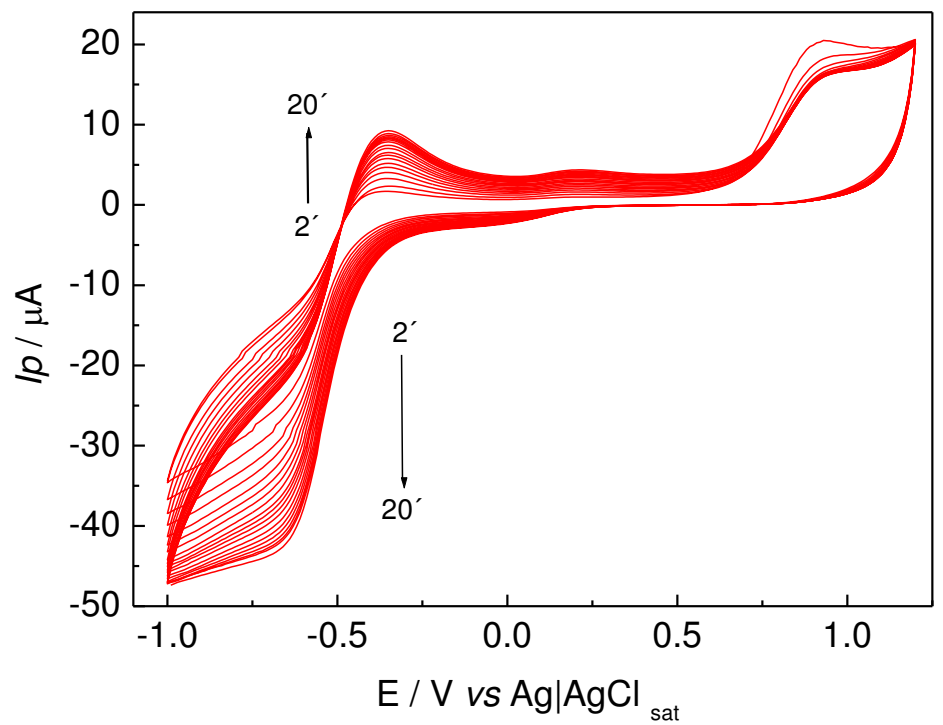

Figure 3. Poly-neutral red electropolymeralization using successive cycles (from $2^{\text {nd }}$ to $20^{\text {th }}$ ) onto composite electrode surface

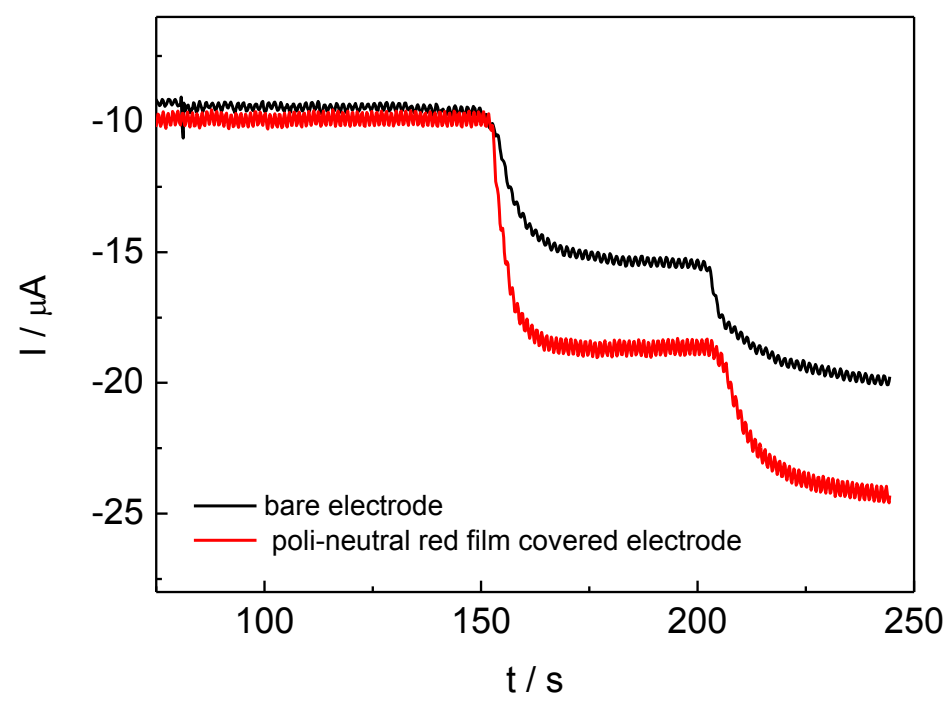

Figure 4. Diverse amperometric behaviours toward hydrogen peroxide addictions $\left(500 \mu \mathrm{L} \mathrm{H} \mathrm{H}_{2}\right.$ $30 \%)$ 


\subsection{Deposition of a copper thin film}

To this deposition, the amperometric detection, which uses the electric current as a response of an electrochemical event, was used. However, it was chosen due to the fact that Faraday's laws could be directly applied in order to obtain copper as a metal on the electrode's surface, in other words, $\mathrm{Cu}^{0}$.

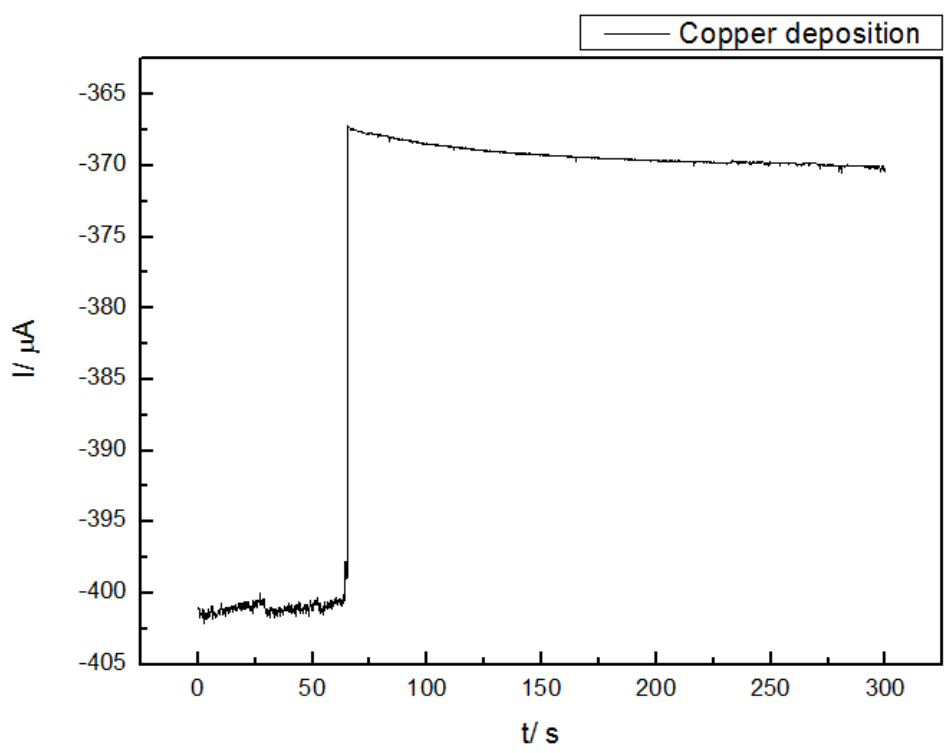

Figure 5. Amperometric profile of the electrodeposition process of copper on the composite

In order to verify the electrode's improvement, a linear region was done comparing the electrode's response with copper and without it, obtaining the graphic represented in Figure 6 . As can be seen, the

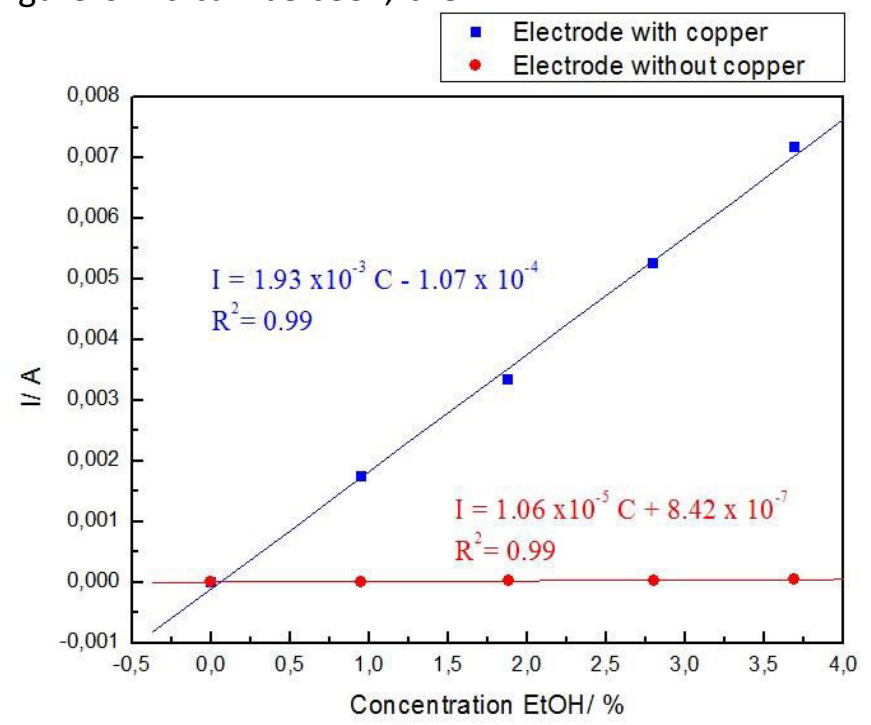

Figure 6. Comparison between the electrode responses with copper in blue and without it in red

electrode's response has grown significantly, demonstrated with an angular coefficient 180 times bigger for the electrode with the electrodeposition of the copper. 


\section{Conclusions}

These studies with the composite electrode, regarding the versatility, easy manipulation, low cost and easy surface renovation, demonstrate the analytical applicability of the graphite paraffin composite electrode. Its possibility of modification has also demonstrated the possibility of multiple applications. In this way, the material has many advantages, mainly considering the low cost when compared with the other techniques used to the same analysis, which are more robust and expensive.

Future steps aim to enlarge the electrode applications in order to use the material as modification platform to other polymers and also to use it as supercapacitors, and more.

\section{Acknowledgements}

The group is grateful to Faperj, CNPq and Proppi-UFF, for their financial support.

\section{References}

${ }^{1}$ Milton, G. W.; The theory of composites, University of Utah: Cambridge, 2004.

${ }^{2}$ Oliveira, A. Dissertação de Mestrado, Universidade Federal de São Carlos, Brasil, 2004.

${ }^{3}$ Semaan, F. S.; Pinto, E. M.; Cavalheiro, E. T. G.; Brett, C. M. A. Electroanalysis 2008, 20, 2287. [CrossRef]

${ }^{4}$ Kalcher, K.; Svancara, I.; Buzuk, M.; Vytras, K.; Walcarius, A. Monatsh. Chem. 2009, 140, 861. [CrossRef]

${ }^{5}$ Mendes, R. K.; Claro-Neto, S.; Cavalheiro, E. T. G. Talanta 2002, 57, 909. [CrossRef] [PubMed]

${ }^{6}$ Oliveira, A.; Santos, S.; Cavalheiro, E. T. G. Talanta 2008, 74, 1043. [CrossRef] [PubMed]
${ }^{7}$ Barsan, M. M.; Pinto, E. M.; Florescu, M.; Brett, C. M. A. Anal. Chim. Acta 2009, 635, 71. [CrossRef] [PubMed]

${ }^{8}$ Beaunier, L.; Keddam, M.; García - Jareño, J. J.; Vicente, F.; Navarro - Boulais, J. J. Electroanal. Chem. 2004, 566, 159. [CrossRef]

${ }^{9}$ McCreery, R. L. Chem. Rev. 2008, 108, 2646. [CrossRef] [PubMed]

${ }^{10}$ Kissinger, P. T.; Heineman, W. R. Laboratory techniques in electroanalytical chemistry, 2a. ed., Marcel Dekker: New York, 2006.

${ }^{11}$ Guth, U.; Vonau, W.; Zosel, J. Meas. Sci. Technol. 2009, 20, 1. [CrossRef]

${ }^{12}$ Ioana Corb, I.; Manea, F.; Radovan, C.; Pop, A.; Burtica, G.; Malchev, P.; Picken, S.; Schoonman, J. Sensors 2007, 71, 2626. [CrossRef]

${ }^{13}$ Mattos, I. L.; Gorton, L. Quím. Nova 2001, 24, 200. [CrossRef]

${ }^{14}$ Karyakin, A. A. Electroanalysis 2001, 13, 813. [CrossRef]

${ }^{15}$ Tseng, K. S.; Chen, L. C.; Ho, K. C. Sens. Actuators, B 2005, 108, 738. [CrossRef]

${ }^{16}$ Moscone, D.; D’Ottavi, D.; Compagnone, D.; Palleschi, G. Anal. Chem. 2001, 73, 2529. [CrossRef] [PubMed]

${ }_{17}$ Orellana, M.; Ballesteros, L.; Del Rio, R.; Grez, P.; Schrebler, R.; Córdova, R. J. Solid State Electrochem. 2009, 13, 1303. [CrossRef]

${ }^{18}$ Shaidarova, L. G.; Davletshina, L. N.; Budnikov, G. K. J. Anal. Chem. 2006, 61, 502. [CrossRef]

${ }^{19}$ Hazen, R.; Spaulding, R. M.; Kasem, K. K.; Sigle, E. A. Am. J. Undergraduate Res. 2003, 2, 27. [Link]

${ }^{20}$ Barsan, M. M.; Pinto, E. M.; Brett, C. M. A. Electrochim. Acta 2008, 53, 3973. [CrossRef]

${ }^{21}$ Ghica, M. E.; Brett, C. M. A. Electroanalysis 2006, 18, 748. [CrossRef]

22 Lange, U.; Roznyatovskaya, V.; Mirsky, V. M. Anal. Chim. Acta 2008, 614, 1. [CrossRef][PubMed]

${ }^{23}$ Barsan, M. M.; Pinto, E. M.; Brett, C. M. A. Phys. Chem. Chem. Phys. 2011, 13, 5462. [CrossRef] [PubMed] 
${ }^{24}$ Pauliukaite, R.; Ghica, M. E.; Barsan, M. M.; ${ }^{25}$ Paixão, T. R. L. C.; Corbo, D.; Bertotti, M. Brett, C. M. A. Anal. Lett. 2010, 43, 1588. Anal. Chim. Acta 2002, 472, 123. [CrossRef] [CrossRef]

${ }^{26}$ Riyanto, M. R. O.; Salimon, J. Malays. J. Anal. Sci. 2007, 11, 379. [Link] 